\title{
Barriers for Use of Wood in Architecture: The Latvian Case
}

\author{
Antra Vil̦uma, Riga Technical University \\ Uǵis Bratuškins, Riga Technical University
}

\begin{abstract}
Wood in general is a traditional building material in Northern Europe including Latvia and other Baltic countries, but nowadays it is used less in Latvia than in other EU countries. There are many forests in Latvia and a well-developed timber industry. Latvian society is enthusiastic about eco-materials, and qualified architects and engineers are ready to work with timber structures. However, wood is mainly used for small buildings and residential construction, but minimally in public and multi-apartment buildings. The study was carried out among architects and other stakeholders in Latvia to analyze their impact on the selection of building material. Thirty-eight interviews were conducted, questionnaire among 73 respondents carried out, and discussion in a focus group was held to find out the main reason and barriers for using wood for buildings in Latvia less than in other EU countries. During the research the main influencing factors for choosing wood constructions were identified and seven main barriers formulated. The study results were compared with the results of similar studies in other countries. Two of the seven barriers in Latvia-stereotypes and legislation - were not mentioned in other studies, nevertheless, these are the most frequently mentioned obstacles in the Latvian case.
\end{abstract}

Keywords - Wood, timber, building material, architecture, construction, barriers, Latvia.

\section{INTRODUCTION}

Timber is a renewable building material that is sustainable in many ways: as a tree, it contributes to mitigate level of carbon dioxide $\left(\mathrm{CO}_{2}\right.$ in the atmosphere [1], [2] and to the development of local economy when harvested and processed locally. The scale of construction in Latvia is growing, however, only a limited part of buildings of various architectural complexity are built using wooden materials. Latvia is a country of forests and timber and has a valuable store of building materials, which sometimes are called green gold. Timber has been used in construction for centuries, however during the last decades in Latvia it is used less than in other EU countries. Identification of weaknesses in the use of wood materials in construction in Latvia is an essential part in the improvement of the situation as well as in mitigating climate change. Wood has the climate change mitigation effect as trees and other living biomass absorb and store $\mathrm{CO}_{2}$. The more the forest grows, the more it is harvested and replaced with new trees, the more $\mathrm{CO}_{2}$ is removed from the atmosphere and absorbed. Trees absorb $\mathrm{CO}_{2}$ in the growing phase and the absorption slows down as trees mature. From the perspective of climate change and efficient resource use, the harvested biomass should be used as a material as long as possible, before using it to generate energy [2].

There are many forests and a well-developed timber industry in Latvia. Several local companies produce timber products including panels and modules for the construction industry, but about $90 \%$ of production is for the export to other EU countries [3], since there is little demand on the domestic market for them. There are only about $1-3 \%$ wooden buildings erected in Latvia per year. The Latvian society is positively disposed towards ecology and sustainability in such sectors as food, clothing, decoration materials and also in the construction of small scale houses. There is less care about climate changes, lifecycle index and reducing ecological footprint and emissions of $\mathrm{CO}_{2}$.

There are several studies in other countries on the attitude of architects and engineers to wood as a structural material. The data had been analyzed by using decision making [11] and planned behavioural theories [4], [5]. Use of wood in public buildings and multi-storey buildings was investigated as well [9], [13]. The framework of interviews and questionannaires was created by using the planned behaviour theory and decision making process in order to find out the barriers for use of wood materials.

The present paper studies Latvia's experience. The study was carried out among architects and other stakeholders in Latvia to analyze their knowledge and experience about the use of wood materials and their impact on the process of selection of building materials. Twenty five interviews were conducted, data from 73 questionnaires was analyzed, and a discussion in focus group was held in order to find out the main reasons and barriers causing limited use of wood materials for buildings in Latvia.

\section{Methods}

The research was planned in three phases by using qualitative and quantitative data methods of analysis. They were evaluated and compared with the research methods used in other similar studies [6]. Finaly, structured interviews, questionnaire and focus group were selected as the most appropriate methods to reach the goal of the study.

\section{A. Structure of Interviews}

To understand an interest of architects and other stakeholders (engineers, developers, municipality and timber industry representatives) in wood as a structural material, structured interviews were organized. The framework of interviews was based on the theory of planned behaviour [7], [8] and other research [5], [9], [10] information. Three main parameters - attitude, subjective norms and perceived behavioral control, were included in the framework of interviews. Architects from practices of different size and one architect from a property development company were interviewed. Interviews were held also with four engineers, 
four municipality representatives, three timber industry representatives and two developers (Table I). The interviews were held face-to-face, mainly, at respondents' offices. Each interview was transcribed and sent to the interviewees for the clarification and approval [12]. The interviews took place till January 2016.

$$
\text { TABLE I }
$$

The Number of Conducted Interviews [Authors of the Article]

\begin{tabular}{|l|c|c|}
\hline Stakeholders & Amount & \% \\
\hline Architects & 25 & 65 \\
\hline Engineers & 4 & 11 \\
\hline $\begin{array}{l}\text { Municipality } \\
\text { representatives }\end{array}$ & 4 & 8 \\
\hline $\begin{array}{l}\text { Timber industry } \\
\text { representatives }\end{array}$ & 3 & 5 \\
\hline Developers TOTAL & 38 & 100 \\
\hline
\end{tabular}

\section{B. Questionnaire and Survey}

In February 2016, after the structured interviewing period a short questionnaire using findings from the interviews was developed in order to find out the distribution of opinions in a wider audience, The online questionnaire survey was used to increase the effectiveness of data collation and analysis. The questionnaire was sent out to people interested in the topic and was part of the registration process for the seminar "Wood in Architecture-Eperience in Latvia and Sweden" and put on the web pages of the Latvia Association of Architects and Riga Technical University. The questionnaire comprised 7 questions about the main barriers for using wood as a building material. There were 73 answers from 85 registrated persons of which 36 were architects, 25 were students and lecturers, as well as representatives from timber production and media.

\section{Focus Group}

The final part of the research was organized as a professional focus group by inviting stakeholders (architects, engineers, producers of timber constructions, developers, municipality representatives) and collecting their opinion. The discussion was organized in the Riga City Architect's office to validate the findings in structural interviews and questionnaire. There were eight invited participants related to or interested in increasing the use of the timber structures. But during the process of organising the focus group the interest about the discussion was so high that the number of participants in the focus group was increased to twelve. The discussion was led by an experienced moderator and the participants were asked direct and indirect questions regarding wood as structural material. The themes and questions were harmonized with the information from interview questions and answers of the structured interview. Also, information about barriers was used from the questionnaire. The discussion session was recorded and a report and transcription were developed. During the discussion process the findings of the structured interviews and questionnaire were verified.

\section{Results}

\section{A. Stakeholders' Attitude to Wood as a Building Material}

Seven problem areas affecting the possibilities of use of wood in buildings were defined from the structured interviews with stakeholders (Table II). All problem areas were mentioned also during the discussion in the focus group.

\section{B. Architects}

Most of the architects have had previous personal experience in using wood. Some of them had designed single family houses using wood or renovation projects of wooden buildings. Two architects had had an experience with pre-fabricated building projects and one architect had worked on a project using cross laminated timber. The attitude of architects to wood as a structural material in general was very positive. They agreed that because of the Fire Safety Regulation (Latvian Construction Standard LBN 201-15) it is not easy to find solutions for using wood in construction. In several interviews a question - who has to convince the customer - was raised. Is it an architect's duty, or is an architect just a professional supporting the customer who would like to have a wooden building? There were also architects who were convinced that wood industry should strive for changes in legislation in order to promote the use of wood.

\section{Civil Engineers}

There were four structured interviews with civil engineers working in structural design. One of the interviewees had worked at a pre-fabricated wood building factory and pointed out such important benefits of using wood modules or panels in construction as time and money saving. All engineers pointed out that legislation, i.e. Latvian Construction Standards and Eurocode 5, is the main obstacle complicating wider use of wooden materials.

\section{Municipality Representatives}

Authorities from municipalities mentioned insurance as an important barrier. Even if building costs are not high further insurance costs increase the total cost of the building. It was mentioned that in Riga as the capital city, legislation or Fire Safety Regulation sets the limits to the height of buildings. For example, in Riga historical centre, which is a UNESCO world heritage site, the height limit of buildings is 21.3 metres, while for wooden structures the maximal height is reduced to only 9.0 meters. This is the reason why the developers usually avoid choosing wooden structures. This issue was widely discussed during the focus group because there were representatives from National Heritage Inspection. Existing wooden buildings are saved as heritage in the historical part of the city, while there are very few new wooden buildings constructed, mostly in cases when the contracting authority has a special aim to build a timber structure.

\section{E. Developers}

The main argument for using or not using wood in projects was the customer's or end-user's attitude or the existing stereotype in society that wooden buildings are not of good quality or there 
TABLE II

The Problem Areas and Frequency of Mentions in Structured Interviews [Authors of the Article]

\begin{tabular}{|c|c|c|c|c|c|c|c|}
\hline & Legislation & Information & Consultations & Qualification & Stereotypes & Knowledge & Experience \\
\hline Architects & 11 & 6 & 5 & 7 & 11 & 8 & 7 \\
\hline Civil Engineers & 4 & 2 & 3 & 3 & 4 & 2 & 2 \\
\hline Municipality representatives & 4 & 1 & 3 & 1 & 3 & 2 & 2 \\
\hline Timber industry representatives & 3 & 1 & 2 & 1 & 3 & 2 & 1 \\
\hline Developers & 2 & 2 & 2 & 1 & 2 & 1 & 2 \\
\hline TOTAL & 24 & 12 & 15 & 13 & 23 & 15 & 14 \\
\hline
\end{tabular}

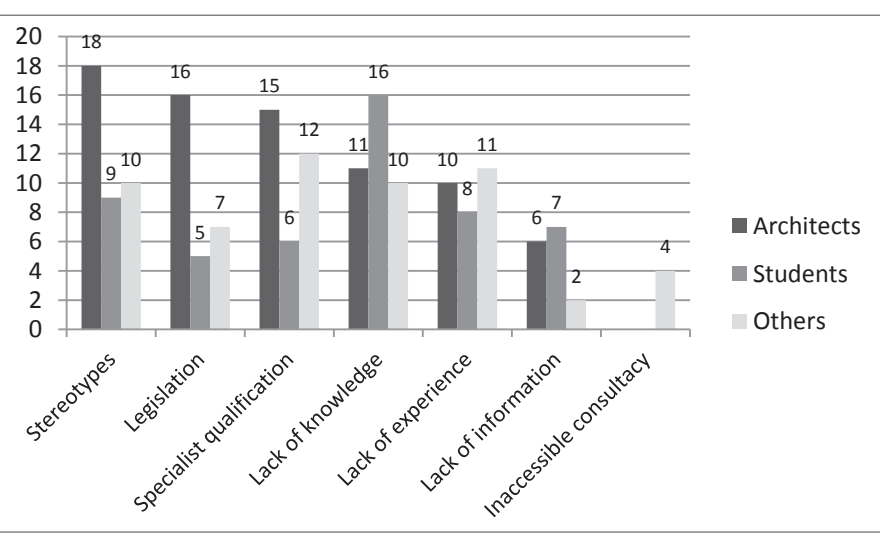

Fig. 1. The main barriers for using wood as a building material [Picture: A. Viļuma, U. Bratuškins].

could be problems with energy efficiency in winter. However, the data from North European and Baltic countries concerning energy efficiency of timber structures demonstrate good results. Image of wood as material mainly for countryside and small buildings also does not convince customers in marketability of multi-apartment buildings with wood panels or of wood modules. The private investors and developers as well as public customers are interested in pilot projects or lighthouse projects. This was also one of the findings of the focus group discussion.

\section{F. The Main Barriers for Use of Wood Materials and Consequences}

The main barriers impeding the use of wood as a building material that result from the interviews are legislation, lack of knowledge, lack of experience, inaccessible consultancy, lack of information, specialists' qualification and stereotypes. The list of participants of online questionnaire comprises 25 architecture and other students, 36 architects and 12 other interested parties, therefore the answers were divided into three groups (Fig. 1).

Each group selected different main barriers. The evaluation of all audience responses showed three barriers that were most frequently flagged. It was Lack of knowledge, Specialists qualification and Stereotypes. But two barriers - Inaccessible consultancy and Lack of information, were selected less often.

The architects (Fig. 2) highlighted the Stereotypes as the main barrier out of the seven given possibilities. The next important

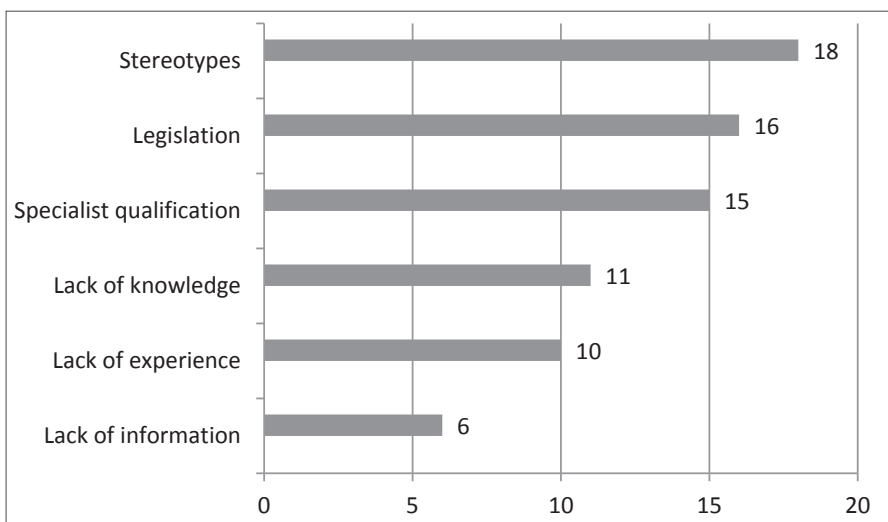

Fig. 2. The main barriers for using wood as a building material in architects' answers [Picture: A. Viḷuma, U. Bratuškins].

barrier that has been mentioned was Legislation. Also, $50 \%$ of architects opted for the Specialists qualification. The barriers - Lack of knowledge and Lack of experience, received equal evaluation.

The architecture students (Fig. 3) opted for the lack of knowledge as the main barrier out of seven given possibilities. They marked as barriers also Lack of experience and Lack of information. As many students were not familiar with Building Codes and other regulations, the least marked barrier amongstudents was Legislation.

Other respondents (Fig. 4) likewise tagged Specialists qualification, Lack of experience, Stereotypes and Lack of knowledge. About half of other respondents (timber industry, economy, etc.) highlighted Legislation as a barrier. The least marked barriers were Inaccessible consultancy and Lack of information.

The questionnaire gave seven different reasons for wood not being widely used as a building material and only $21 \%$ of participants chose one out of the seven barriers (Fig. 5). Two or three reasons were marked by $59 \%$ of the respondents, but $20 \%$ of participants selected four or five barriers.

The analysis of the number of the selected barriers by different respondent groups reflected that the group of architecture students mentioned two or three barriers more than other groups. Architects most often marked two barriers, though often one and three barriers were also chosen. 


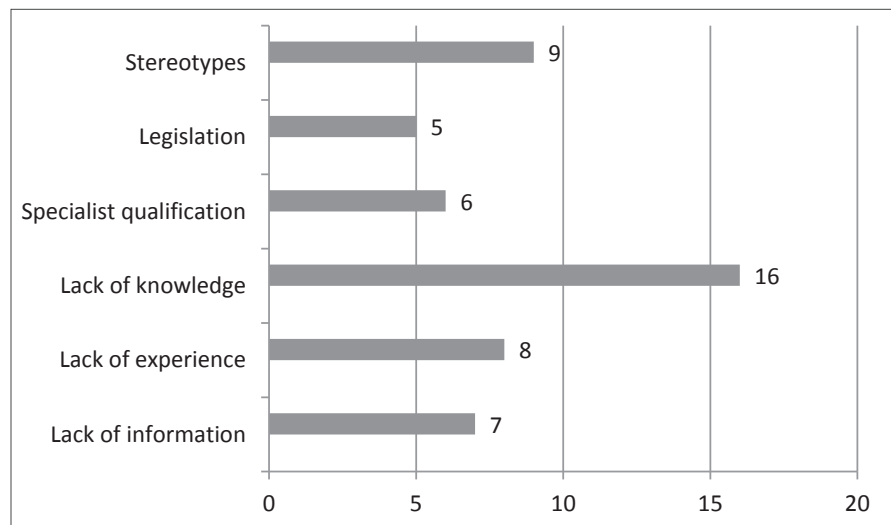

Fig. 3. The main barriers for using wood as a building material in students' answers [Picture: A. Viḷuma, U. Bratuškins].

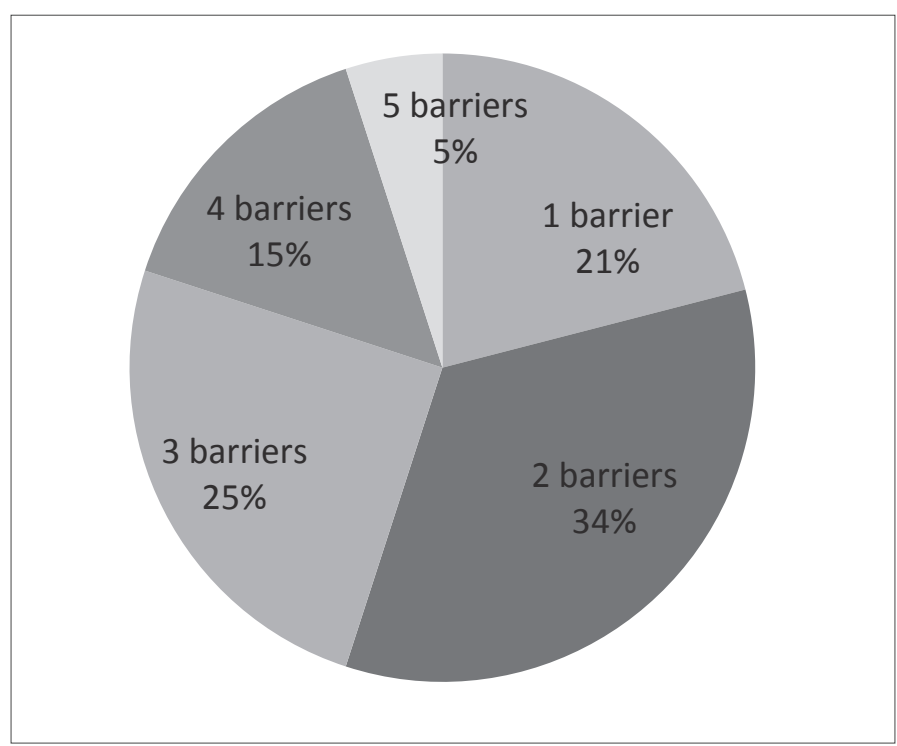

Fig. 5. Frequency of marked barrier for each respondent [Picture: A. Vil̦uma U. Bratuškins].

The result is similar to the data from interviews - the legislation and stereotypes were the main barriers mentioned during interviews with architects, but they mentioned also some additional reasons.

The barrier Inaccessible consultancy was not specified either by architects or by architecture students. The reason was it being understood as knowledge and experience. The situation was similar in the case with with barrier Lack of informationit was mentioned, but less than Lack of knowledge and Lack of experience. One of the most noted barriers was Legislation and it was the opinion of architects who have had direct relation to Construction Standards.

\section{Discussion}

The interpretation of the results of the structured interviews, the online questionnaire and focus group generally matched the

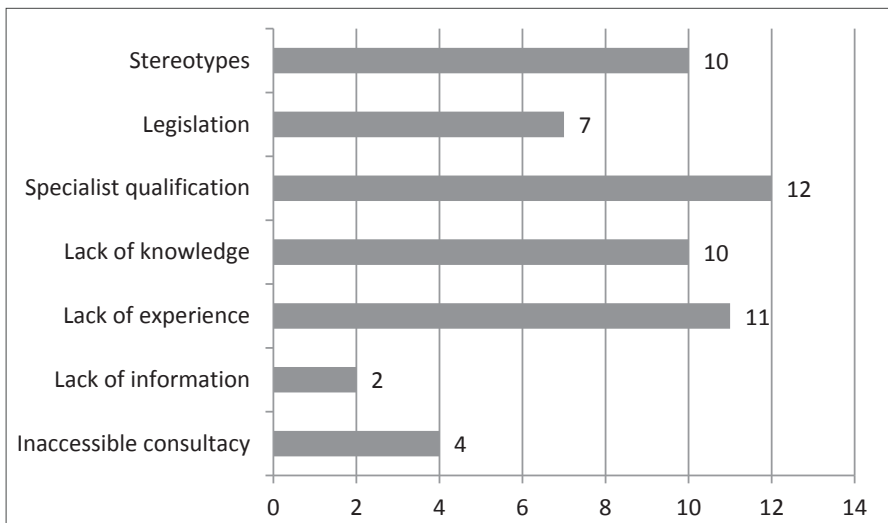

Fig. 4. The main barriers for using wood as a building material in the answers of other respondents [Picture: A. Vil̦uma, U. Bratuškins].

results from studies made in other countries. However, the results of the research in Norway [10] present only two of these barriers lack of knowledge and lack of experience. Mainly interviews with architects and engineers [5], [9], [10] outline current issues - the barriers impeding the use of wood as a building material and the factors influencing the choice of wood. Five main influencing factors for choosing wood constructions are related to experience (help and support), perceived risk (not enough experience), fire properties, visual properties and perceived behavioral control (there are several factors for not changing the choice of material).

Due to the barriers, stereotypes and legislation in other studies are not mentioned. In all parts of the research, both factors were highlighted in different ways. The legislation was an essential barrier from the architects' point of view, however it was mentioned also by engineers, developers and municipality representatives. It could be related to Latvian Construction Standards where Fire regulation (LBN 201-15) limits the height of buildings instead of design performance of the construction. Sometimes legislation was mentioned as the only barrier for using wood in multi-apartment and non-residential buildings, but the data from other studies demonstrate that after changing the Construction Standards and Fire regulation there still remain other barriers.

During the focus group the representatives of the timber production industry expressed an idea that a pilot project is needed to distribute knowledge and experience to all parties involved: producers, architects and engineers and also local authorities and other monitoring bodies.

Examples of successful wood construction projects were mentioned in other studies [10], [13] and it could minimize possible risks. High priority would be given to workshops or seminars transferring knowledge and expertise of more experienced architects and engineers, as well as technical and professional information with the actual updates and consultations. Research results show that architects and engineers, the contracting and control authorities as well as timber industry representatives should change their attitude in order to increase the use of wood constructions in practice. 


\section{CONCLUSion}

The barriers identified in the study are both subjective (stereotypes, lack of information) and objective (legislation, lack of experience). The only fixed barrier for wood structure usage in architecture is Latvian Construction Standard for Fire Safety regulation LBN 201-15, which is more restrictive than prohibitive document. The Latvian Construction Standard permits the performance based use of wood or use of timber constructions if it is justified by calculations or tests. To overcome this barrier additional resources for architects and engineers (time and calculations) as well for developers (finance) are needed. In other countries there are different instruments to support the specialists, e.g. free tutorial for timber projects in Canada, supportive network Nordic Wood Cities in Scandinavia, etc. The research has also shown that the removing of the restriction on the use of wood will not cause major changes in the choice of building materials. It is directly related to the lack of information and knowledge of stakeholders and society on the use of wooden features and properties as well as to experience of architects and engineers. Even if architects are willing and able to work with wood using it in their projects, they are not "use of wood" advocates and are not always ready to persuade the customer.

It is important to be aware that it is difficult to change stereotypes, or more precisely, they cannot be changed. It is much better to create new stereotypes, e.g. it is prestigious to live in a wooden house.

\section{REFERENCES}

1. Werner, F., Taverna, R., Hofer, P., Thurig, E., Kaufmann, E. National and global greenhouse gas dynamics of different forest management and wood use scenarios : a model-based assessment. Environmental Science \& Policy, Vol. 13, No. 1, 2010, pp. 72-85. https://doi.org/10.1016/j.envsci.2009.10.004

2. Upton, B., Miner, R., Spinney, M., Heath, L. S. The greenhouse gas and energy impacts of using wood instead of alternatives in residentia construction in the United States. Biomass and Bioenergy, Vol. 32, No. 1, 2008, pp. 1-10. https://doi.org/10.1016/j.biombioe.2007.07.001

3. Petrane, L. Latvijā palēnām sāk novērtêt koka māju būvniecību [online] $w w w . d b . l v$ [cited 18.04.2017]. http://www.db.lv/ipasums/buve/latvija-palenam-sak-novertet-koka-maju-buvniecibu-456782

4. Wang, L., Toppinen, A., Juslin, H. Use of wood in green building: A study of expert perspectives from the UK. Journal of Cleaner Production, Vol. 65, 2014, pp. 350-361. https://doi.org/10.1016/j.jclepro.2013.08.023

5. Roos, A., Woxblom, L., Mecluskey, D. The influence of architects and structural engineers on timber in construction - perceptions and roles Silva Fenn., Vol. 44, No. 5, 2010, pp. 871-884. https://doi.org/10.14214/ sf.126

6. Gylling, G., Knudstrup, M., Heiselberg, P. K., Hansen, E. K. Measuring sustainable homes - a Mixed Methods approach. Media, No. April, 2011, pp. 20-24.

7. Ajzen, I. The theory of planned behavior. Organizational Behaviour and Human Decision Processes, Vol. 50, No. 2, 1991, pp. 179-211. https://doi. org/10.1016/0749-5978(91)90020-T

8. Ajzen, I. Nature and operation of attitudes. Annu. Rev. Psychol., Vol. 52, No. 1, 2001, pp. 27-58. https://doi.org/10.1146/annurev.psych.52.1.27

9. Kozak, R. A., Cohen, D. H. Architects and structural engineers: An examination of wood design and use in nonresidential construction. Forest Products Journal, Vol. 49, No. 4, 1999, pp. 37-46.

10. Bysheim, K., Nyrud, A. Q. Using a predictive model to analyze architects' intentions of using wood in urban construction. Forest Products Journal, Vol. 59, No. 7/8, 2009, pp. 65-74.

11. Edwards, W. The theory of decision making. Psychological Bulletin Vol. 51, No. 4, 1954, pp. 380-417.

12. Ridder, H. G., Yin, R. K. Case Study Research. Design and Methods Zeitschrift Für Personalforschung, Vol. 26, No. 1, 2012, pp. 93-96.
13. Mahapatra, K., Gustavsson, L., Hemström, K., Multi-storey wood-frame buildings in Germany, Sweden and the UK. Construction Innovation, Vol. 12, Issue 1, 2012, pp. 62-85. https://doi. org/10.1108/14714171211197508

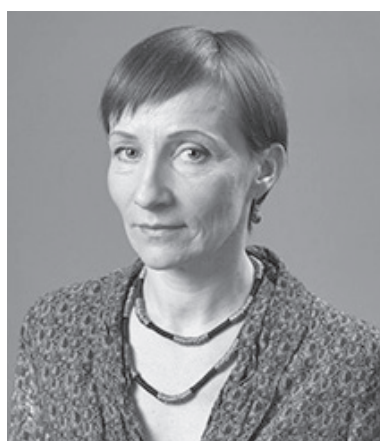

Antra Viḷuma, Mg. Arch. graduated from the Faculty of Architecture of RTU in 1992. In 2003, she received the degree of Master of Communication from the University of Latvia. She has worked in construction industry, public relations and marketing, and has written for the several media. Since 2012, she has been engaged in projects on wooden architecture, participated in scientific conferences on wooden construction, has been a guest editor of the special issue on wooden architecture of the magazine "Latvijas Arhitektūra", and a member of the jury of annual competition "Award of Riga Architecture 2016". She has been the coordinator of international projects with the Riga Energy Agency and City Development Department.

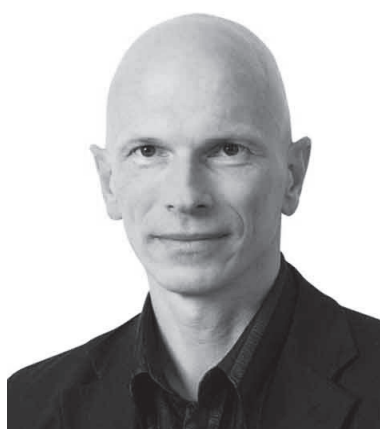

Uǵis Bratuškins, Dr. arch., is currently an architect (b. 1961), Professor with Riga Technical University, the Dean of the Faculty of Architecture. He received the degree of Master of Architecture in 1994 and the degree of Doctor of Architecture in 2006. Since 1984 , he has been a practicing architect with the design bureau Komunālprojekts Ltd. and Sestais Stils Ltd. He is a member of the Latvian Association of Architects. $\mathrm{He}$ is an author and co-author of many public and dwelling buildings in Riga and other towns of Latvia. His major projects are Renovation of Riga Town Hall Square (Riga City Council Building and Extension, Museum and Chamber Music Hall building The House of the Black Heads, Office buildings), interiors of the Faculty of Social Sciences of University of Latvia. $\mathrm{He}$ is a member of Editorial Boards of such journals as Architecture and Urban Planning (Riga, Latvia), Journal of Architecture and Urbanism (Vilnius, Lithuania), Landscape Architecture and Art (Jelgava, Latvia) and Journal of Sustainable Architecture and Civil Engineering (Kaunas, Lithuania). He is an expert at Fondazione Romualdo Del Bianco (Florence, Italy) and Slovenian Research Agency (Ljubljana, Slovenia). He is author of more than 60 publications.

\section{Contact Data}

\section{Antra Viliuma}

Faculty of Architecture,

Riga Technical University

Adress: 6 Kīipsalas St., Riga, LV-1048

Phone: +371 29464411

E-mail: antra.viluma@rtu.lv

\section{Uǵis Bratuškins}

Faculty of Architecture,

Riga Technical University

Adress: 6 Kīpsalas St., Riga, LV-1048

E-mail: ugis.bratuskins@rtu.lv 